\title{
KREATIVITAS ANAK NAGARI DALAM PEMBUATAN KERAJINAN BESI DI KENAGARIAN AIA BANGIH KABUPATEN PASAMAN BARAT
}

\author{
Asyraful Anami \\ Jurusan Pendidikan Luar Sekolah \\ FIP Universitas Negeri Padang \\ E-mail : asyraful_anami@yahoo.co.id
}

\begin{abstract}
Penelitian ini bertujuan untuk mendeskripsikan dan mendapatkan data, dan membahas tentang Kreativitas Anak Nagari Dalam Pembuatan Kerajinan dari besi di nagari Aia Bangih Pasaman Barat dilihat dari : pribadi kreatif. pendorong kreatif. proses kreatif. produk kreatif. Jenis penelitian ini tergolong pada penelitian Deskriptif Kualitatif studi kasus . Subjek penelitian adalah Anak Nagari yang bekerja sebagai pengrajin besi. Pengumpulan data melalui observasi, observasi partisipatif, dan wawancara., pengambilan kesimpulan merupakan pencarian pola,tema,. Kesimpulan membutuhkan triangulasi sumber. Hasil penelitian menunjukkan bahwa: Kepribadian pengrajin besi harus mempunyai kecerdasan,mandiri, dalam menekuni suatu usaha kerajinan dari besi, harus di iringi dengan motivasi intrinsik dan ekstrinsik. Dari hasil temuan penelitian dikemukakan saran sebagai berikut Kepada Anak Nagari pengrajin besi, supaya lebih giat menekuni usaha kerajinan dari besi, Besar harapan peneliti supaya pengrajin besi lebih fokus dan lebih berinovasi dengan memanfaatkan teknologi sebagai alternatif.
\end{abstract}

Kata kunci: Kreativitas, Anak Nagari, kerajinan besi.

This research purposes to describe and to get the data, and discuss about Creativity of Local villager of iron's handicraft in Aia Bangih West Pasaman views of: personal creative. factor creative. the creative process. creative products. kind of research is relatively descriptive research on case studies. Subjects research is workers as iron's craft. The data collection through observation, participant observation, and interviews. The conclusion is taking search patterns, themes, relationships equations and hypotheses against data already dimatrik. conclusion need verification. The Examination to the validity of the data is divided into three criteria namely Triangulation source. Results showed that: Personality iron craftsman must intelligence, self-contained, open new experiences, in an effort to develop creativity, in an effort to pursue craft of iron, must be accompanied by a motivation intrinsik and extrinsic. From research findings put forward suggestions as follows: to local villager iron craftsmen, so that more vigorous pursue the iron's craft, Major steel producers hope that researchers focus more and more innovate by leveraging technology as an alternative.

Keyword: Creativity, Local villager, Manufacture, Iron's craft. 


\section{Pendahuluan}

Pendidikan dilakukan tidak hanya melalui pendidikan persekolahan tetapi juga melalui pendidikan masyarakat (non formal). Hal ini sesuai dengan UU RI NO 20 Tahun 2003 tentang Sistem Pendidikan Nasional bahwa "Jalur pendidikan terdiri atas pendidikan formal (sekolah) jalur pendidikan non formal (masyarakat) dan jalur pendidikan informal (keluarga) yang dapat saling melengkapi dan memperkaya”.

Menurut Supriyadi (1998:7)

Bahwa kreativitas adalah kemampuan seseorang untuk melahirkan sesuatu yang baru baik berupa gagasan maupun karya nyata yang relatif berbeda dengan apa yang ada sebelumnya. Orang-orang kreatif berhasil mencapai ide, gagasan, pemecahan, penyelesaian, cara kerja, hal atau produk baru biasanya sesudah melewati proses kreatif.

Sebagaimana yang dilakukan oleh Anak Nagari di Kenagarian Aia Bangih Kec. Sungai Beremas Kab Pasaman Barat sebagai pelaku pembangunan yang dapat mengembangkan kreativitas dengan menekuni pembuatan kerajinan dari besi. Usaha besi berkembang sejalan dengan kemampuan menimbulkan ide, gagasan dan kemampuan berkreasi untuk menghasilkan produk yang kreatif. Anak Nagari juga berkosentrasi penuh dengan kegiatan yang di hadapinya.

Selama ini masalah kreativitas Anak Nagari Aia Bangih yang menghasilkan kerajinan dari besi belum pernah dikaji secara akademik atau ilmu pengetahuan. Hasil observasi yang peneliti lakukan sudah banyak karya kreatif yang diciptakan Anak Nagari yang kreatif seperti pembuatan tempat tidur koi untuk acara adat di Kenagarian Aia Bangih, yang bahan dasarnya tetap dari besi.

Tolak ukur yang menjadikan Anak Nagari dapat mengembangkan kreativitasnya dengan penentuan kriteria kreatifitas yang peneliti lakukan pada usaha kerajinan dari besi ini. 
Kriteria yang dimaksud yaitu menyangkut kepada empat aspek yaitu: proses kreatif dalam mencipta, pendorong kreatif, kepribadian yang kreatif dari Anak Nagari ( person ) produk atau karya kreatifitas dari Anak Nagari. Menurut Amble dalam Supriyadi ( 1998:15) "Bahwa menggunakan proses kreatif sebagai kriteria kreativitas maka segala produk yang dihasilkan dari proses itu dianggap sebagai produk kreatif dan orangnya disebut sebagai kepribadian atau prilaku yang kreatif.

Setiap individu memiliki kecenderungan atau dorongan mewujudkan potensinya, mewujudkan dirinya, dorongan berkembang menjadi matang, dorongan mengungkapkan dan mengaktifkan semua kapasitasnya, dorongan ini merupakan motivasi primer untuk kreativitas ketika individu membentuk hubungan-hubungan baru dengan lingkungannya dalam upaya manjadi dirinya sepenuhnya. (Rogers dan Vernon 1982)

Dari proses berfikir kreatif untuk menciptakan karya kreatif para pengrajin besi juga mempergunakan alat kerja yang modren untuk menghemat tenaga, biaya dan meningkatkan kualitas barang atau produk, berkat kreatifnya sekarang mereka sudah memakai gerenda generator,ragum atau roller press, bor listrik,mesin bubut dan Blower yang memanfaatkan tenaga listrik dan mesin.

Pada awalnya peneliti melakukan observasi ke "Kobun Teknik" atau bengkel las abang Afkar yang mana pada Kobun Teknik itu menciptakan kerajinan seperti pembuatan tempat tidur koi untuk acara adat di Kenagarian Aia Bangih sesuai dengan permintaan konsumen.

Fenomena yang terlihat pada saat sekarang ini ialah, yang mana Anak Nagari lebih cendrung untuk mempelajari keterampilan pembuatan kerajinan dari besi dibandingkan dengan kerajinan lainnya, dengan berbagai hasil yang telah dicapai Anak Nagari pada saat sekarang ini sudah banyak karya kreatif yang diciptakan Anak Nagari yang kreatif dan unik seperti: pembuatan tempat tidur koi untuk acara adat di Kenagarian Aia Bangih, motif pagar 
besi,pintu besi,sangkar besi dan masih banyak lagi jenis barang yang lain yang bahan dasarnya tetap dari besi, maka dari itu peneliti tertarik untuk melakukan penelitian di Kenagarian Aia Bangih Kec. Sungai Beremas Kab Pasaman Barat.

Dari hasil observasi sekaligus wawancara pada tanggal 20 desember 2011 dengan Anak Nagari yang menjalankan usaha keterampilan ini,peneliti bisa menarik suatu kesimpulan bahwa untuk menekuni usaha sampai mencapai puncak kesuksesan perlu adanya minat, bakat, konsentrasi, sikap, kemandirian,seni dan keluasan fikiran serta kepribadian lainnya terhadap proses kerja atau keterampilan yang dijalankan. Pengembangan motif dan kreatifitas dirasa semakin penting manfaatnya karena tuntutan dari selera konsumen terhadap barang atau karya kreatif yang diciptakan dan sebagai akibat semakin ketatnya persaingan diantara usaha yang sejenis.

Menurut Hardjana ( 1986:11)

Bahwa kreativitas adalah kegiatan yang mendatangkan hasil yang sifatnya : (1)Baru : inovatif,belum ada sebelumnya ,segar, menarik dan mengejutkan (2) Berguna: lebih enak, praktis, mempermudah, memperlancar, mendorong, mengembangkan, mendidik, memecahkan masalah, mendatangkan hasil lebih baik (3) Dapat dimengerti: hasil yang sama dapat dimengerti dan dibuat dilain waktu.

Dari kutipan diatas bahwa jelas proses keterampilan Anak Nagari memang harus bersifat baru,berguna dan dapat dimengerti baik itu oleh pencipta maupun pemakai barang. Hari demi hari Anak Nagari yang menekuni keterampilan ini selalu memodifikasi hasil dari barang kerajinan agar selalu dibutuhkan oleh masyarakat umum seperti motif Pagar Besi.Dimana Anak Nagari yang menekuni keterampilan ini selalu mengembangkan kreativitasnya dan berlomba-lomba menjadi pengrajin barang yang berkualitas tinggi.

Tujuan penelitian ini adalah untuk menjawab pertanyaan penelitian yang telah diajukan dalam penelitian ini dengan rincian tujuan sebagai berikut: 
1. Menggambarkan kreatif pribadi ( personal ) Anak Nagari dalam pembuatan barangbarang kerajinan dari Besi di Kenegarian Aia Bangih Kec Sungai Beremas Kab Pasaman Barat.

2. Menggambarkan pendorong kreatif Anak Nagari dalam pembuatan barang-barang kerajinan dari Besi di Kenegarian Aia Bangih Kec Sungai Beremas Kab Pasaman Barat.

3. Menggambarkan proses kreatif Anak Nagari dalam pembuatan barang-barang kerajinan dari Besi di Kenegarian Aia Bangih Kec Sungai Beremas Kab Pasaman Barat.

4. Menggambarkan produk kreatif Anak Nagari dalam pembuatan barang-barang kerajinan dari Besi di Kenegarian Aia Bangih Kec Sungai Beremas Kab Pasaman Barat.

Menurut Munandar (1995:25)

kreativitas adalah suatu kemampuan umum untuk menciptakan suatu yang baru, sebagai kemampuan untuk memberikan gagasan-gagasan baru yang dapat diterapkan dalam pemecahan masalah, atau sebagai kemampuan untuk melihat hubungan-hubungan baru antara unsur-unsur yang sudah ada sebelumnya.

Menurut Julius (1994:13) "Kreativitas adalah dinamika yang membawa perubahan yang berarti, entah dalam dunia kebendaan, dunia ide, dunia seni, atau struktur sosial”.

Menurut Mangunhardjana (1986:11)

adalah kegiatan yang mendatangkan hasil yang sifatnya berguna (useful), lebih enak, lebih praktis, mem-permudah, memperlancar, mendorong, mengembangkan, mendidik, memecahkan masalah, mengurangi hambatan, mengatasi kesulitan, mendatangkan hasil lebih baik atau banyak. 
Salah satu tugas Pendidikan Nasional yaitu" mengembangkan iklim belajar mengajar yang dapat memupuk sikap dan prilaku kreatif, inovatif'. Berdasarkan pemikiran tersebut sasaran yang ingin dituju dalam pendidikan adalah mencerdaskan kehidupan bangsa yang berdimensi kreativitas akan terwujud jika potensi yang ada pada warga belajar sebagai sumber daya manusia belum diungkapkan secara baik dan menyeluruh,. Dimensi kreativitas itu sendiri secara makro merupakan unsur kekuatan sumberdaya manusia yang handal untuk mengarahkan pembangunan nasional melalui perannya dalam penelusuran, pengembangan dan penemuan IPTEK.dan faktor inilah yang sebenarnya menjadi kunci sukses Negara Maju didunia.

Dalam pengembangan kreativitas masalah pokok yang perlu diketahui adalah memahami secara benar pokok persoalan yang menyangkut konsep kreativitas,ciri-ciri kreativitas atau rumusan dengan tolak ukur dan cara atau teknik serta instrumen yang dapat digunakan untuk itu.

Menurut Penulis, kreativitas adalah kemampuan umum untuk menciptakan sesuatu yang baru dan membawa perubahan serta mendatangkan hasil yang sifatnya berguna yang berupa gagasan maupun karya nyata dan diiringi dengan dorongan dan dukungan internal maupun eksternal.

Guilford dalam tim dosen MKDK (2002:65) dengan analisis faktornya mengemukan juga lima ciri yang menjadi sifat kemampuan berfikir kreatif diantaranya (1) Kelancaran adalah adanya ide yang banyak dan luas, kaya dalam perbendaharaan kata dan cara menyampaikan sesuatu (2) Keluwesan adalah digunakannya ide baru dalam mengenal permasalahan (3) Keaslian, adalah difikirkannya ide-ide dan kemungkinan-kemungkinan yang tidak biasa atau ganjil (4) Elaborasi, masalah dipakainya berbagai rincian dalam mengemukakan sesuatu atau merespon. 
Di dalam pendidikan luar sekolah keterampilan tidak hanya membutuhkan ketekunan juga harus mengembangkan kreativitas dalam meningkatkan mutu keterampilan. Sebagaimana yang dikemukan oleh Supriyadi dalam tim dosen MKDK (2002:70) "Bahwa untuk mengembangkan kreativitas, interaksi antara faktor lingkungan dan kepribadian merupakan faktor penentu apakah seseorang mampu melahirkan prestasi kreatif yang istimewa dalam lapangan ilmu pengetahuan ataupun dalam bidang lain”.

\section{Metode Penelitian}

Penelitian yang penulis buat menggunakan pendekatan kualitatif, sebagaimana yang dikemukakan oleh Moleong (2006:17) yaitu (1) Metodologi kualitatif menyajikan secara langsung hubungan peneliti dengan responden, (2) Menyesuaikan metode kualitatif lebih mudah apabila berhadapan dengan kenyataan ganda, (3) Metode kualitatif lebih cepat dan lebih peka menyesuaikan diri dengan penajaman pengaruh bersama dan terhadap pola-pola yang dihadapi. Disamping fenomena keterampilan dalam proses pembelajaran yang selalu berkiprah dalam dunia usaha pembuatan barang-barang kerajinan yang terbuat dari besi merupakan kegiatan keterampilan Anak Nagari yang kegiatannya dilakukan setiap hari.

Sedangkan jenis penelitian ini tergolong kepada jenis studi kasus, karena peneliti mencoba mengamati jalannya kreativitas yang menjadi aktifitas Anak Nagari dalam menekuni pembuatan barang kerajinan dari besi dilapangan sebagai upaya memperoleh gambaran yang utuh dari objek yang diteliti.

Jenis data dalam penelitian ini adalah lebih banyak kepada tatacara kekreatifan aktor dalam aktivitas pembuatan kerajinan dilapangan, baik itu person (pribadi kreatif), pendorong kreatif, proses kreatif dan produk kreatif. Kemudian setelah itu disusun dalam bentuk kalimat sampai aktor sebagai Anak Nagari yang menekuni kerajinan ini, bisa memainkan peran sebagai seorang yang bisa mengembangkan kreativitas melalui keterampilan dalam usaha barang kerajinan dari besi. 
Sedangkan sumber data adalah subjek dan informan. Sumber data subjek adalah orang yang terlibat dalam kegiatan pengembangan kreativitas dalam proses pembuatan barangbarang kerajinan dari besi. Informannya adalah beberapa orang dari induk semang dan anak buah yang dianggap tahu dan telah terampil dalam keterampilan pembuatan barang-barang kerajinan ini.

Dalam pengumpulan data ada beberapa cara yang dilakukan yaitu teknik observasi, observasi partisipatif dan wawancara. Teknik observasi partisipatif dilakukan dengan langkah melakukan penyamaran dengan ikut terjun mengamati ketermpilan itu sehingga situasi dan kondisi tetap terjaga dengan baik, untuk itu peneliti bisa mengumpulkan data setelah hubungan kondusif bagi pengumpulan data.

Peneliti menggunakan triangulasi sebagai teknik untuk mengecek keabsahan data. Dimana dalam pengertiannya triangulasi adalah teknik pemeriksaan keabsahan data yang memanfaatkan sesuatu yang lain dalam membandingkan hasil wawancara terhadap objek penelitian (Moloeng, 2004:330)

Analisa data dilakukan selama penelitian berlangsung mulai dari perencanaan, pengumpulan data sampai tahap penyusunan laporan dan penarikan kesimpulan. Meskipun laporan telah ditulis kesimpulan akan ditarik jika terdapat keraguan dari data yang diperoleh. Model analisis data yang digunakan adalah model analisis yang dikemukakan oleh Moleong 2006 yang terdiri dari tiga langkah yaitu : Reduksi data, Display data, dan Pengambilan kesimpulan.

\section{Hasil dan Pembahasan}

Semua hasil temuan akan digambarkan sesuai dengan kondisi yang ada di lapangan yang berkaitan dengan bagaimana Anak Nagari Aia Bangih melaksanakan aktivitasnya 
didalam pembuatan barang kerajinan dari besi. Selain dari paparan hasil temuan penelitian ini, juga berisikan tentang pembahasan dan untuk lebih rincinya pembahasan hasil temuan di lapangan akan dipaparkan melalui cuplikan dari kegiatan Anak Nagari yang dibuat melalui catatan lapangan peneliti.

\section{Gambaran Umum}

\section{1) Letak Dan Administrasi}

Secara administratif Kenagarian Aia Bangih berada di dalam Kecamatan Sungai Beremas, Kabupaten Pasaman Barat, Provinsi Sumatera Barat, dengan letak geografis Nagari Aia Bangih berada pada $00^{\circ} 09^{\prime}-00^{\circ} 31^{\prime}$ LU dan $99^{\circ} 10^{\prime}-99^{\circ} 34^{\prime}$ BT. Nagari Aia Bangih mempunyai luas daerah $183,47 \mathrm{Km}^{2}$ dengan ketinggian dari permukaan laut 0 - 659 meter. Nagari Aia Bangih merupakan satu-satunya nagari yang terdapat di Kecamatan Sungai Beremas.

Kecamatan Sungai Beremas Pada awalnya merupakan gabungan dari sembilan desa yang ada di Kecamatan Sungai Beremas yang diantaranya yaitu Desa Koto Jambuo, Desa Pasar Suak, Desa Pasar Muara, Desa Pasar Baru, Desa Pasar Pokan, Desa Bunga Tanjung, Desa Kampung Padang, Desa Silawai dan Desa Pulau Panjang yang ibu kota Kecamatannya terletak di Aia Bangih. Aia Bangih Sebagai Ibu Kota Kecamatan Sungai Beremas melingkupi beberapa desa yang diantaranya, Desa Koto Jambuo, Desa Pasar Suak, Desa Pasar Muara, Desa Pasar Baru, Desa Pasar Pokan, dan Desa Kampung Padang.

Setelah dilakukannya pemekaran pada tahun 2003 maka sembilan desa yang terdapat di Kecamatan Sungai Beremas tersebut di gabungkan menjadi satu nagari dengan nama Nagari Aia Bangih sehingga desa-desa tersebut menjadi jorong. Pada saat ini Nagari Aia Bangih mempunyai 15 Jorong, yaitu Jorong Pasar Satu, Jorong Pasar Dua Suak, Jorong pasar Baru Barat, Jorong Pasar Baru Timur, Jorong Pasar Baru Utara, Jorong Pasar Muara, Jorong 
Kampung Padang Utara, Jorong Kampung Padang Selatan, Jorong Pasar Pokan, Jorong Silawai, Jorong Silawai Timur, Jorong Pulau Panjang, Jorong Pigogah Patibubur, dan Jorong Ranah Panantian

\section{2) Jumlah Penduduk}

Berdasarkan data kependudukan dari kantor Wali Nagari Tahun 2012, jumlah penduduk Kenagarian Aia Bangih 27.275 jiwa terdiri dari 12.119 jiwa laki-laki dan : 14.120 jiwa perempuan, sedangkan jumlah kepala keluarga 5.416 KK. Untuk lebih jelasnya berikut ini akan disajikan komposisi penduduk Nagari Aia Bangih berdasarkan Jumlah Penduduk Dirinci Menurut Umur Dan Jenis Kelamin.

Semua hasil temuan akan digambarkan sesuai dengan kondisi yang ada dilapangan yang berkaitan dengan bagaimana Anak Nagari Aia Bangih melaksanakan aktivitasnya didalam pembuatan barang kerajinan dari besi. Selain dari paparan hasil temuan penelitian bab ini juga berisikan tentang pembahasan dan untuk lebih rincinya pembahasan hasil temuan di lapangan akan dipaparkan melalui cuplikan dari kegiatan Anak Nagari yang dibuat melalui catatan lapangan peneliti.

\section{Gambaran Khusus}

\section{1) Gambaran Pribadi yang kreatif dalam pembuatan barang kerajinan dari besi}

Sebelum memaparkan beberapa komponen pribadi dalam kriteria kreativitas ini, perlu dikemukakan bahwa komponen pribadi dalam kriteria kreativitas mengacu kepada kepribadian atau watak seseorang untuk melakukan aktivitas sebagai seorang pengrajin besi yang merupakan salah satu pendidikan luar sekolah khususnya pendidikan masyarakat.

Mac Kinon dalam James R. Evans (1991:59) mengemukakan 6 ciri-ciri pribadi yang kreatif diantaranya : (1) Cerdas (2) Mandiri (3) Terbuka (4) Intuitif (5) Menjunjung tinggi teori dan estetika (6) Berani dan teguh hati. 
Lebih lanjut menurut Munandar dalam Supriyadi (1998:60) mengemukakan 7 ciri-ciri sikap pribadi yang kreatif yaitu : (1) terbuka pada pengalaman baru dan luar biasa (2) luwes dalam berfikir dan bertindak (3) bebas dalam mengekpresikan diri (4) dapat mengapresiasi fantasi (5) berminat pada kegiatan-kegiatan kreatif (6) percaya pada gagasan sendiri (7) mandiri

Dalam pribadi seorang pengrajin besi, untuk melakukan kegiatannya mereka mampu berfikir secara tepat dan lebih luas karena hasil penelitian yang peneliti temukan mereka melakukan aktifitas tidak sekadar mengisi waktu melainkan bertekat untuk mencapai target dengan hasil yang memuaskan bagi konsumen yang mengorder koi, pada saat Peneliti bertanya "kalo seandainya koi permintaan konsumen tidak siap dengan kurun waktu satu hari bagaimana bang?" si Pengrajin menjawab, “Oooo kalo untuk sampai saat sekarang ini pesanan koi dari konsumen selalu siap dalam satu hari, kami akan mengusahakannya siap dengan kondisi dan kualitas barang yang dijamin bagus dan tahan lama, kemaren ada juga terkendala masalah bahan yang kurang, tapi kami sebagai pengrajin harus semaksimal mungkin mengusahakan bahan, meskipun bahan itu jauh kami dapatkan, sampai-sampai ke nagari ujung gading, yang penting kita harus menepati janji kepada konsumen”.

Dari hasil cuplikan di atas peneliti dapat melakukan triangulasi sumber sebagai pemeriksaan keabsahan data, menurut keterangan konsumen dan masyarakat setempat barang yang dihasilkan sangat bagus sekali kualitasnya dan proses pengerjaannya hanya kurun waktu satu hari, bahwa seorang pengrajin harus mampu memberikan layanan terbaik kepada konsumen dan masyarakat yang mana seorang pengrajin juga harus pintar mempergunakan waktu dalam mengerjakan barang pesanan dari konsumen, supaya target pengerjaan barang bisa siap dalam waktu yang telah ditentukan oleh pengrajin besi di Kenagarian Aia Bangih. 


\section{2) Gambaran Pendorong kreatif Anak Nagari dalam pembuatan barang kerajinan dari Besi}

Sebelum memaparkan beberapa komponen pendorong dalam kriteria kreativitas ini, perlu dikemukakan bahwa komponen pendorong dalam kriteria kreativitas mengacu kepada motivasi baik yang datang dari dalam maupun dari luar.

berdasarkan wawancara sebelumnya si Pengrajin disuruh untuk buka usaha Bengkel las, dan pada kesempatan ini Peneliti bertanya, "apakah ada dorongan dari diri abang sendiri sebelum menekuni usaha kerjinan besi yang sampai sekarang abang jalani?’. Dengan tertawa kecil si Pengrajin menjawab, “ hmmm, dorongan dari diri tentu ada, seiring dengan usaha keluarga pada saat itu menurut saya sangat bagus untuk dikembangkan, dengan kebutuhan masyarakat Nagari Aia Bangih yang sangat bervariasi sekali yang berkaitan dengan besi,apa salahnya saya kembangkan, itu kepikiran saya waktu itu.

Dari hasil wawancara peneliti dengan pengrajin,paman pengrajin dan teman sejawat pengrajin peneliti dapat melakukan triangulasi sumber sebagai pemeriksaan keabsahan data, bahwasanya untuk menekuni suatu usaha kerajinan dari besi, harus di iringi dengan motivasi intrinsik atau dorongan dari individu itu sendiri, guna untuk memberikan semangat dan sebagai upaya untuk lebih meningkatkan usaha dan percaya diri dengan apa yang akan dikerjakan sesuai dengan harapan dan tujuan sebagai pengrajin besi.

\section{3) Gambaran Proses kreatif Anak Nagari dalam pembuatan barang kerajinan dari} besi. 


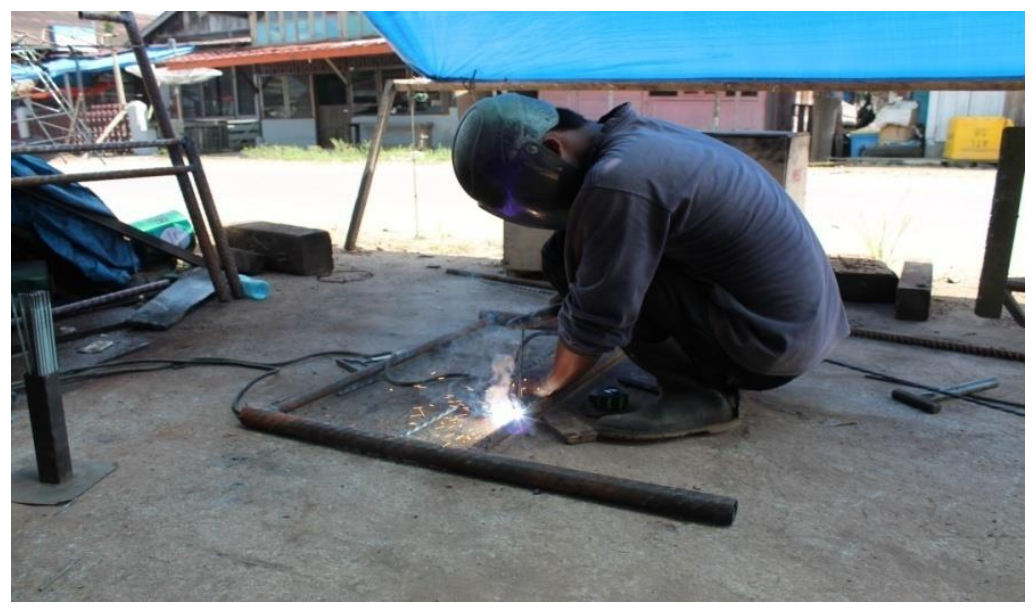

\section{Gambar 1 : Proses Pembentukkan Kerangka Koi}

Dalam aktifitas proses kreatif dapat di artikan sebagai upaya pencarian ide-ide yang mampu meberikan arahan kepada pelaksanaan dan dapat di iringi oleh keinginan serta harapan untuk bisa mewujudkannya kedalam kehidupan nyata, Menurut Rothenberg dalam supriyadi (1998:13) bahwa proses kreatif identik berfikiran jenius yaitu suatu tipe divergen yang berusaha melihat berbagai dimensi yang beragam atau mungkin bertentangan menjadi sesuatu pemikiran yang baru dan inovasi. Proses kreatif yang dimaksud dalam usaha pengembangan kreatifitas pembuatan kerajinan dari besi yang dimaksud adalah usaha Anak Nagari untuk melahirkan sesuatu ide yang baru dan sekaligus mengambil tempat sebagai pelaku kreatif.

Dari kutipan dan hasil wawancara yang peneliti lakukan, bahwasanya sudah terlihat jelas kepribadian dan proses kerja yang dilaksanakan oleh pengrajin dibengkel kobun teknik sangat membutuhkan konsentrasi yang ekstra dan terfokus demi mengharapakan hasil yang berkualitas dan lebih unggul dari bengkel yang lain, dengan menggunakan teknik dan metode yang khas sesuai dengan ide yang mereka gagas secara otodidak tanpa mendapatkan pendidikan formal, dengan berbekal kemandirian dan pengelaman kerja, sampai sekarang mereka masih eksis dalam proses pembuatan barang kerajinan dari besi di Kenagarian Aia Bangih. 


\section{4) Gambaran Produk kreatif Anak Nagari dalam pembuatan barang kerajinan dari} besi.

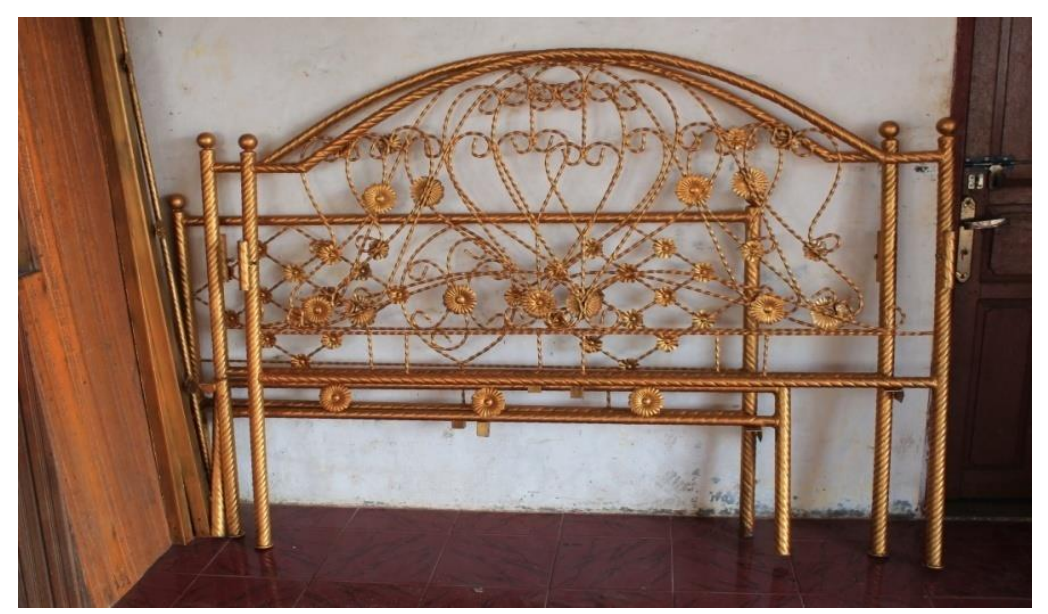

\section{Gambar 1 : Koi Hasil Dari Produk Kreatif Anak Nagari Aia Bangih Dalam Menekuni Usaha Kerajinan Dari Besi.}

Produk kreatif merupakan hasil dari pribadi yang kreatif serta proses kreatif itu adalah suatu kondisi yang dapat memungkinkan seseorang menciptakan produk kreatif yang penuh arti, kreativitas untuk produk kreatif adalah bisa menampilkan produk nyata dan produk hasil dari tangan kreatif yang unik dari individu dalam interaksi dengan lingkungan sekitarnya, sehubungan dengan itu temuan peneliti yang berkaitan dengan produk kreatif adalah hasil proses kreatif dan produk kreatif yang disukai.

Kemudian dilain waktu peneliti sempat mengutip pembicaraan pengrajin dengan seorang konsumen yang datang dari pulau panjang.

Dari hasil cuplikan percakapan antara pengrajin dengan konsumen yang jauh-jauh dari pulau panjang, peneliti pun bisa mengambil kesimpulan, bahwasanya produk kreatif mempunyai suatu daya tarik tersendiri, dengan kualitas barang yang tidak diragukan lagi konsumen lebih mengetahui mana kualitas yang baik dan mana kualitas yang kurang baik dan di iringi dengan informasi antara masyarakat yang berada di daerah Kenagarian Aia Bangih.

\section{Kesimpulan}


Berdasarkan gambaran tentang kriteria kreativitas kerajinan Anak Nagari sebagai pengrajin besi dan pembahasan yang telah dikemukakan peneliti dapat ditarik suatu kesimpulan sebagai berikut :

1. Gambaran pribadi kreatif (personal) Anak Nagari memiliki suatu kepribadian yang berani dan teguh hati dalam menyelsaikan suatu pekerjaan. Dengan demikian, kita bisa tahu apa dan bagaimana untuk mengantisipasi kecelakaan kerja, yang sering menimpa pengrajin.

2. Gambaran pendorong kreatif Anak Nagari, di iringi dengan motivasi intrinsik atau dorongan dari individu itu sendiri dan ekstrinsik atau dorongan dari lingkungan sekitar individu, seiring dengan rasa percaya diri pengrajin, dan ditambah dukungan dari teman-teman pengrajin.

3. Gambaran proses kreatif Anak Nagari, dari segi kepribadian dan proses kerja yang dilaksanakan oleh pengrajin di bengkel kobun teknik sangat membutuhkan konsentrasi yang ekstra dan terfokus, demi mengharapakan hasil yang berkualitas dan lebih unggul.

4. Gambaran produk kreatif Anak Nagari, sebuah kreativitas yang dimiliki seorang individu, apabila menemukan tempat atau wadah yang sesuai dengannya, tidak tertutup kemungkinan akan bisa membantuk seuatu yang bernilai guna, seperti usaha Anak Nagari dalam menekuni usaha pembuatan barang kerajinan dari besi di Kenagarian Aia Bangih Kecamatan Sungai Beremas Kabupaten Pasaman Barat.

\section{Saran}

Dari hasil temuan penelitian dilapangan yang telah disimpulkan maka peneliti dapat mengemukakan beberapa saran yang ingin disampaikan diantaranya sebagai berikut: 
1. Kepada Anak Nagari, semoga setelah ada penelitian ini Anak Nagari lebih berani lagi dalam berinovasi dan mengeksplorasi diri baik itu dari bidang yang bersifat umum (suatu bidang kerja yang bisa dilakukan oleh semua orang) maupun bidang yang bersifat khusus (bidang kerja yang hanya bisa dilakukan oleh sebagian orang saja), karena pada hakikatnya itu akan menimbulkan jiwa positif bagi individu itu sendiri.

2. Kepada Masyarakat, Peneliti sangat berharap supaya lebih mengapresiasi hasil produk anak nagari daripada hasil atau karya dari luar nagari, karena di samping bisa meningkatkan daya kreativitas Anak Nagari, apresiasi dari masyarakat juga bisa menimbulkan dan membentuk jiwa Anak Nagari yang lebih bertanggung jawab terhadap suatu usaha ataupun pekerjaan yang dilakoninya.

3. Khusus bagi pengrajin besi di Kenagarian Aia Bangih, untuk bisa lebih fokus dan lebih berinovasi dengan memanfaatkan teknologi sebagai alternatif guna untuk lebih meningkatkan kualitas kerja dan kualitas produk untuk ke depannya.

4. Sebagai Anak Nagari peneliti berharap semoga pemerintah setempat bisa menjalin kerja sama dengan pengrajin dalam program pemberdayaan dan pelatihan kecekapan hidup guna untuk mengembangkan potensi dan mengembangkan kreativitas Anak Nagari sebagai generasi perubahan.

\section{DAFTAR RUJUKAN}

Chandra, Julius. 1994. Kreativitas. Yogyakarta : Kanisius

Evans, James R. 1991. Berfikir Kreatif. Jakarta : Bumi Aksara

http://www.maindexchange.com

http://www.psychologymania.com/2012/11/peranan-orangtua-dalam-pengembangkan.html

Ibrahim,Maghazi.2005. Menumbuhkan Kreativitas Anak. Jakarta : Cendekia

Moleong, Lexy. 2006. Metodologi Penelitian Kualitatif. Bandung: Remaja Rosda

Munandar, Utami. 2004. Pengembangan Kreatifitas Anak Berbakat. Jakarta: Rhineka cipta 
Munandar, Utami. 1992.. Mengembangkan Bakat dan Kreatifitas Anak Sekolah.Jakarta: Gramedia Widiasrama indonesia.

Mangunhardjana. 1992. Mengembangkan Kreatifitas. Yogyakarta :Kanisius

Supriyadi, didi. 1998. Kreatifitas Kebudayaan dan Perkembangan Iptek.

TIM dosen Pembinaan Mata Kuliah Perkembangan Peserta Didik. 2002. Perkembangan Peserta Didik. IKIP Padang.

UU RI NO 20 tahun 2003. Sistem Pendidikan Nasional 